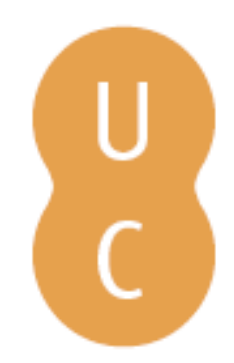

\title{
pommalina
}

\section{The Brics and the challenges of global economic governance}

\author{
Autor(es): Thorstensen, Vera \\ Publicado por: Imprensa da Universidade de Coimbra \\ URL \\ persistente: \\ URI:http://hdl.handle.net/10316.2/43161 \\ DOI: \\ DOI:https://doi.org/10.14195/978-989-26-1433-5_6
}

Accessed : $\quad$ 26-Apr-2023 14:38:42

A navegação consulta e descarregamento dos títulos inseridos nas Bibliotecas Digitais UC Digitalis, UC Pombalina e UC Impactum, pressupõem a aceitação plena e sem reservas dos Termos e Condições de Uso destas Bibliotecas Digitais, disponíveis em https://digitalis.uc.pt/pt-pt/termos.

Conforme exposto nos referidos Termos e Condições de Uso, o descarregamento de títulos de acesso restrito requer uma licença válida de autorização devendo o utilizador aceder ao(s) documento(s) a partir de um endereço de IP da instituição detentora da supramencionada licença.

Ao utilizador é apenas permitido o descarregamento para uso pessoal, pelo que o emprego do(s) título(s) descarregado(s) para outro fim, designadamente comercial, carece de autorização do respetivo autor ou editor da obra.

Na medida em que todas as obras da UC Digitalis se encontram protegidas pelo Código do Direito de Autor e Direitos Conexos e demais legislação aplicável, toda a cópia, parcial ou total, deste documento, nos casos em que é legalmente admitida, deverá conter ou fazer-se acompanhar por este aviso. 


\section{Euro-Atlântico:}

\section{Espaço de Diálogos}

Isabel Maria Freitas Valente

Iranilson Buriti de Oliveira

(Coord)

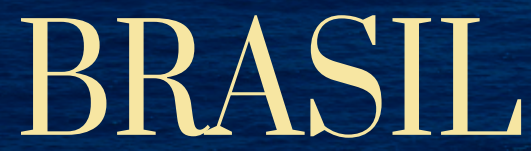

NAS ONDAS

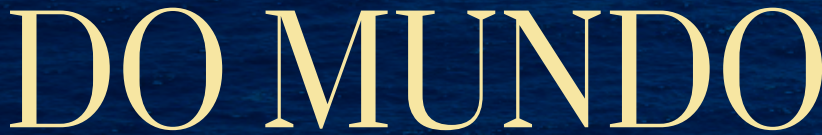

Álvaro Vasconcelos (Org)

Editora da Universidade Federal de Campina Grande

Imprensa da Universidade de Coimbra

2017 


\title{
THE BRICS AND THE CHALLENGES OF GLOBAL ECONOMIC GOVERNANCE
}

Vera Thorstensen, $P b D$ Escola de Economia de São Paulo da FGV

E-mail: vera.thorstensen@fgv.br

Lucas Ferraz, $P h D$

Escola de Economia de São Paulo da FGV E-mail: Lucas.Ferraz@fgv.br

\begin{abstract}
The objective of this paper is to explore how new challenges are affecting the Global Trading System and how it can evolve to face them. They are: i) the deadlock to move multilateral negotiations at the WTO, ii) the fragmentation of trade rules by the multiplication of preferential agreements, iii) the arrival of a new model of global production and trade leaded by global value chains, and iv) the imposition of new sets of regulations by non-governmental organizations to reflect the concerns of consumers in the North based on their precautionary attitude about sustainability of products made in the World. The consequence is that the lack of any multilateral order in this scenario is creating a cacophony of rules and developing a new regulatory war of the Global North against the Global South.
\end{abstract}

Keywords: Trade challenges; WTO; Preferential agreement; North against South 
A new paradigm is modeling the World: revolutionary digital innovations in all fronts, new information technologies, huge mobility of capital, use of risky financial tools, globalization or regionalization of production and distribution, new emerging powers and the impact of consumer concerns on governmental policies. These phenomena are shaping the World and forcing the advent of a new World Order in the Multilateral Monetary, Financial, and Trading System.

The effects of this new paradigm are also transforming global governance. The political and economic orders established after the World War and centered on the multilateral model of UN, IMF, World Bank, and the GATT, leaded by the developed countries, are facing significant challenges. The rise of China and emerging countries shifted the old model to a polycentric World, where the governance of these organizations are threatened by emerging countries demanding a bigger participation in the role and decision boards of these international bodies. As a consequence, multilateralism is being confronted by polycentrism. Negotiations for a more representative voting process and the pressure for new rules to cope with the new demands are paralyzing important decisions.

A new wave of uncertainties chocked the World after the Brexit vote in the UK and the election of Trump in the US, promising an American much more inward looking, protectionist and against immigration.

This scenario is affecting seriously not the World Economy not only the Monetary and Financial Systems but also the Multilateral Trading System. International trade is facing some significant challenges: a serious deadlock to move multilateral negotiations at the WTO, the fragmentation of trade rules by the multiplication of preferential and new generation agreements and the arrival of a new model of global production and trade leaded by global value chains that is threatening the old trade order, and the imposition of new sets of regulations by private bodies commanded by transnationals to support global value chains and non-governmental organizations to reflect the concerns of consumers in the North based on their precautionary attitude about sustainability of products made in 
the World. The lack of any multilateral order in this new regulation is creating a big cacophony of rules and developing a new regulatory war of the Global North against the Global South.

The objective of this paper is to explore how these challenges are affecting the Trading System and how it can evolve to manage these new trends.

\section{WTO AND THE NEW GENERATION OF PTAS}

\section{Introduction - an impasse at the WTO}

The first challenge of the Multilateral Trading System is how to break the impasse of multilateral negotiations. Since 2002, with the launching of the Doha Round, WTO members are struggling to balance the interests of developed and developing countries under the new geometry of power derived from the rise of the emerging countries. As a response to this impasse, many countries preferred to concentrate political efforts with the negotiation of preferential trade agreements. The only results presented are the Agreement on Trade Facilitation and the end of subsidies on agricultural exports.

Following the history of the WTO, the mandate and timing of the former rounds were decided mainly by the US and the EU. With the emergence of China, India, and Brazil this geometry was shifted and, because the interests could not be accommodated as before, the Doha Round arrived at a big stalemate. With the difficulties to conclude the Doha Round and the challenge to adapt the old trade rules to the new reality, the US and the EU decided to launch a new generation of PTAs with several of their partners. Some examples are the US-Korea, EU-Korea, US-Australia, and US-Chile agreements.

To deal with the new challenges of trade, the US and the EU start negotiating what is being called 21st century PTAs: the Trans-Pacific 
Partnership - TPP (US, Japan, Australia, Brunei, Chile, Malaysia, New Zealand, Peru, Singapore and Vietnam) and the Transatlantic Trade and Investment Partnership - TTIP (US and EU). These two new generation agreements would enclose half of World trade and 40 countries. Behind these two new strategies of the US and the EU were the geo-economic interests of these partners and a response to the aggressive trade and investment policies of China. However, the arrival of the Trump government changed the plans. The US opted to leave the TPP and start negotiating bilateral agreements and reviewing NAFTA using TPP as the new legal framework. In contrast, the EU concluded the CETA with Canada and accelerated negotiations with India and Mercosul.

These new generations are a new sort of agreements. More than the reduction of tariffs, they aim to define a new structure and modalities for all kinds of non-tariff barriers to trade, along with new rules for important trade related issues such as investment, competition and new concerns as environment, climate, labor, food scarcity, animal welfare, digital economy, state-own enterprises, anti-corruption and private standards as the result of a mounting consumer pressure.

Many emerging countries as Brazil, China, and India, as global international traders, prefer to give priority to the multilateral track, where they presume to better influence the trade game and better defend its interests. However, the impasse of the Doha Round was a big failure. After almost two decades, the only tangible but important result is the Agreement on Trade Facilitation.

Other countries, on the contrary, chose to pursue another track: to increase their trade through negotiations of PTAs. This strategy, on the one hand, creates new market opportunities, but on the other hand results in the fragmentation of international trade regulation, creating conflicts and lack of transparency, accountability, coherence, and legitimacy.

There is a new reality that must be confronted. The option for bilateral trade agreements with the Pacific countries by the US contrasted with the preferential agreements by the EU. Nothing was decided yet 
about the future of TTIP, the partnership between the US and the EU. This new scenario will surely benefit its parts but, at the same time, will create uncertainties for all other trade partners. The new fact is that all these initiatives are now based on a new legal framework much more advanced than the one offered by the WTO. Due to their importance, they will establish a new system of rules, probably in conflict with WTO because it will discriminate parts-in from parts-out of these PTA. New rules will occur in areas expanding WTO rules (WTO-plus) as service and intellectual property, but also, with rules in new areas as environment, climate change, labor, investment, competition, state own enterprises and digital economy (WTO-extra rules).

Modern PTAs have, besides ambitious schedules of preferential tariffs, a broad regulatory framework to deal with bilateral international trade flows of goods and services. This set of rules deals with several trade-related activities and may have a direct impact on market access of the preferential trade partners. Thus, this new generation of the preferential regulatory framework allows both to enhance the trade liberalization promoted in by the PTA and to provide tools to protect sensitive sectors from the enlarged market access in their domestic markets. Therefore, the definition of its regulatory framework is as important as the tariff reduction. A proper design of the preferential rules may mitigate the negative effects of trade liberalization on sensitive sectors as well as eliminate regulatory barriers faced by other sectors. Another important fact to be emphasized is that emerging countries are untill now excluded from these new order.

\section{PTAs of the $21^{\text {st }}$ Century: TTP and TTIP}

From the significant amount of information already released about these two new generation agreements, complemented by agreements of the new generation as Korea-US and Korea-EU, some inferences can be developed as the model of PTAs the US and the EU are creating. The ne- 
gotiations of these two new generation agreements present an ambitious agenda, with substantial elimination of tariffs on goods, enlargement of market access in services and government procurement, convergence and cooperation through the harmonization or equivalence of technical, sanitary and phytosanitary measures.

A relevant issue for all emerging countries that are agricultural exporters will be the negotiation by the EU and the US of preferential tariff quotas for agricultural products. The quotas negotiated will impact and reduce the global tariff quotas available by the EU and the US in their agricultural market, significantly harming emerging countries.

The enlargement of market access of the trade partners participating in these two agreements shall have as a certain effect not only the increase in trade flows between these parties, but also a reduction of flows from other emerging countries to these destinies (trade diversion), since emerging countries products will not face this privileged market access.

The agreements will also include several WTO-plus and extra rules such as enhanced intellectual property protection, as proposed by the US in the TPP, regulation of e-commerce, competition rules, liberalization and protection of investments, regulation of trade-related aspects of state-owned enterprises, provisions on small and medium sized enterprises, rules of international supply chains, amongst other themes ${ }^{100}$. One major concern in the development of WTO-plus rules in PTAs is that they will certainly affect all trade player and not only the ones that have directly participated in the negotiation of the PTA.

The rules of deep integration negotiated within those agreements, which regulate behind the border barriers, such as technical regulations and intellectual property, are likely to be extended to all extra players, since these rules imply in a modification of the countries' national leg-

100 FERGUSSON, I.; COOPER, W.; JURENAS, R.; WILLIAMS, B. - The Trans-Pacific Partnership Negotiations and Issues for Congress, Congressional Research Service Report for Congress, June 2013, p. 47-48 and Interim Report to Leaders from the Co-Chairs EU-US High Level Working Group on Jobs and Growth, June 2012 
islation to be applied to all goods or services trade within the territory of the countries include in these new generation agreements. Exports from emerging countries are likely to face new technical and sanitary standards negotiated within the TTIP or enhanced intellectual property protection in patents registered in any of the TPP partners, which may also affect these exports.

\section{The US model of PTAs}

The US has developed over the past years a model of PTA which includes binding rules in a wide range of trade related topics. The text of TPP and the proposals on TTIP, as well as the PTA with Korea (KORUS) that entered into force in the past years could serve as a basis for the new kind of negotiations and indicate what sort of rules shall be proposed by the US in an eventual negotiation with some emerging countries in the future.

Concerning the rules of origin, the most relevant proposal by the US is the maintenance of the yarn forward rule for textiles, already implemented in other agreements. This strict requirement confers origin only for textile products fully produced in one or more member countries of the preferential agreement. This rule of origin can be interesting for some emerging countries textile industry that are complementary to the American industry and that also defends the yarn forward criteria ${ }^{101}$, but are very excluding for third parties.

Regarding trade defense issues, the most relevant clauses present in US agreements are related to sectorial safeguards, applied to agricultural and textile products, during a transition period. PTAs with Australia, Morocco and Chile establish a reference price below which agricultural safeguards can be applied. The agreement with Australia also allows the application of safeguards when exports exceed $110 \%$ of the amount

${ }^{101}$ FIESP - Análise Quantitativa das Negociações Internacionais, São Paulo, 2011, p. 56 
established in the schedule of the PTA ${ }^{102}$. It is likely that the US demands the negotiation of agricultural safeguards in an agreement with any other country, which can harm the country's exports in some competitive agricultural sectors. Efforts should be centered in attenuating the effects of these safeguards, by establishing requirements of serious injury, previous consultations with the other party, compensation mechanism, etc.

For the issues of technical, sanitary and phytosanitary barriers to trade, US PTAs now introduce an important new point, that of regulatory coherence and convergence. These rules include in the agreement a strong mechanism to oblige partners to converge to a common regulations and standards, facilitating trade among them and creating barriers to the excluded ones. They also include mechanisms of mutual recognition among partners. This mechanism will force technical and sanitary requirements present in the legislation of each country to search for equivalent level playing fields and to be recognized by other parties ${ }^{103}$. These negotiations can be of great interest for some agricultural exporters, facing sanitary and phytosanitary barriers when exporting to the US market.

Trade in services is an area of great interest to the US. The country usually demands a negative schedule of commitments in its PTAs, by which only the services sectors that will not be liberalized are listed, rule that include all new technologies not yet developed, rule that is excluded with the model of positive lists. Another particularity of the US model, based on NAFTA, is that it excludes mode 3 (commercial presence) from the rules of trade in services to be regulated as activity

102 CARVAlHO, Marina A. E. - Medidas de Defesa Comercial e Regras de Origem: Panorama de Regulação em Acordos Regionais de Comércio Celebrados por União Europeia, Estados Unidos, China e Índia, Texto para Discussão 1811. IPEA, 2013

103 PIERMARTINI, Roberta; BUDETTA, Michelle - "A Mapping of Regional Rules on technical barriers to trade", in ESTEVADEORDAL, A., et. al., Regional Rules in the Global Trading System. Cambridge: Cambridge University Press, 2009, p. 259 
in the investments chapter. Due to the same reasoning, financial services are also regulated in a separate chapter.

The increase of intellectual property protection is also a major issue for the US. The KORUS agreement has substantially enhanced such protection and proposals on the TPP aim to increase even further the duration of author rights and to strengthen the protection of patents, especially in pharmaceutical and biological products ${ }^{104}$, which can be an issue for the governmental program of generic drugs developed in some emerging countries.

Investments regulation includes clauses regarding the protection of international investments and investor-state arbitration, in the model of bilateral investments agreements (BITs). The regulation of the theme can represent a problem to some emerging countries that reject this arbitration solution as a substitute to their domestic courts. The EU proposal of an investment court could be a solution.

An interesting point is the current debate on the ancient American position regarding the freedom of capital flows. US PTAs usually establish the complete freedom of capital flows, but, due to the financial crisis of 2008, there are some of its partners that argue that capital controls are a necessary measure to promote economic stability in periods of crises and some degree of controls must be allowed. This change in position will possibly be reflected in the future agreements ${ }^{105}$.

Government procurement is also an issue of interest for the US. For some emerging countries, government procurement represents a big market to American exports and the US includes the issue in the negotiations. US agreements frequently prohibit preferential treatment to

104 FRANKEL, S. - "The intellectual property chapter in the TPP". In: LIM, C.L.; ELMS, D.K.; LOW, P. (orgs.). The Trans-Pacific Partnership: A Quest for a Twenty-First-Century Trade Agreement. New York: Cambridge University Press: 2012, pp. 157-170

105 FERGUSSON, I.; COOPER, W.; JURENAS, R.; WILLIAMS, B. - The Trans-Pacific Partnership Negotiations and Issues for Congress, Congressional Research Service Report for Congress, June 2013, p. 39 
national products in procurement covered in its PTAs, which can affect emerging countries governmental programs of development promotion.

The US also regulates competition, environment and social clauses in its agreements as well as the new topics proposed in the negotiations, which point to the extensiveness of the trade regulation and the deep integration sought by the country in its new generation of preferential negotiations.

\section{The EU model of PTAs}

The EU also presents an extensive regulation in a broad range of themes in its PTAs. In its previous agreements, several clauses in themes such as environment, labor, and competition were merely cooperative clauses, with no binding mechanisms. But there has been a recent change towards obligatory clauses in these issues.

Regarding rules of origin, the preferred method by the EU is to establish transformation process for each product, which can result in a complex certification procedure. Some European rules confer origin for products with a low aggregated value in the continent, allowing for products majorly produced in other countries with cheaper labor costs to be eligible to preferences by EU PTA partners. This is a concern to some emerging countries, in relation to exports on footwear, textiles, and paper and paper products industries ${ }^{106}$.

In trade defense instruments, the major concern is, again, the mechanism of agricultural safeguards, presented in EU PTAs which should be a requirement of the bloc in negotiations with other emerging countries.

Technical, sanitary and phytosanitary barriers to trade are usually regulated by the harmonization process, allowing for the export of the

106 FIESP - Análise Quantitativa das Negociações Internacionais - Relatório, São Paulo, 2011, p. 86. 
European standards to each of the partner's domestic legislations ${ }^{107}$. Nevertheless, the negotiations on harmonization clauses and especially mutual recognition ones are of great interest for many emerging countries. Many agricultural exports face SPS barriers and an extensive range of industrial products is directly or indirectly affected by the REACH program, a complex regulation regarding chemicals, which is currently affecting emerging countries sectors of chemicals, electric electronics and textiles ${ }^{108}$.

Trade in services is a market of interest for the EU and the liberalization of several sectors is likely to be demanded. The EU usually follows the model of the GATS, with a positive schedule of commitments where only the sectors to be liberalized are listed, and with the inclusion of mode 3 (investment) in the services chapter. But the recent EU-Korea agreement also regulates the liberalization of investments related to this mode of services ${ }^{109}$.

In intellectual property, the EU also aims to enhance the level of protection and has already established this point as one of the objectives of the TTIP, even though there are some long-standing differences between European and American legislation that would be kept. A topic of great interest for the EU regarding intellectual property is geographic indication for food and wines, which is a point included in all EU agreements.

The regulation of investments in a manner similar with BITs is common in EU PTAs as well and another theme of the TTIP, which aims both liberalization and protection of international investments. The novelty is

107 PIERMARTINI, Roberta; BUDETTA, Michelle - "A Mapping of Regional Rules on technical barriers to trade", in ESTEVADEORDAL, A., et. al., Regional Rules in the Global Trading System. Cambridge: Cambridge University Press, 2009, p. 258

108 FIESP, op. cit p. 86 ss.

109 RORIZ, J.H.R.; TASQUETTO, L.S. - Propriedade intelectual, serviços e investimentos: panorama de regulação em acordos regionais de comércio celebrados por União Europeia, Estados Unidos, China e Índia. IPEA, TD 1801, 2012, p. 46-48 
the introduction of the investment court for the parties of the agreement contrasting with the investor-state arbitration clause ${ }^{110}$.

Government procurement is also regulated in EU PTAs and does not present significant differences if compared with the US model. The chapter usually regulates on non-discriminatory market access, fair and equitable treatment and transparency and it also limits offsets and conditionalities in government procurements covered by the PTA. Furthermore, no or few flexibilities regarding special and preferential treatment for developing countries are allowed ${ }^{111}$.

Competition, environment, and labor clauses have changed in the EU most recent agreements from cooperative to binding clauses. Furthermore, the increasing concern with environment and climate change issues has lead the EU to develop several rules on the subject, mainly in the form of technical standards and the level playing field sought by the bloc in the negotiation of environmental clauses in PTAs may have been increased, which should be reflected in negotiations with other emerging countries.

\section{Simulations of the impacts of TTP and TTIP on the BRICS}

Despite the option of the US moving out of the TPP and substituting it for bilateral agreements, TPP can be considered the new legal framework for new US and TTIP PTAs. Certainly the excluded emerging countries will be affected by these new generation agreements. To give an idea of the dimension of these impacts, this Section will simulate some scenarios with some emerging countries: Brazil, China, India, Russia and South Africa. The modeling considers three sectors: agriculture, industry and

110 Interim Report to Leaders from the Co-Chairs EU-US High Level Working Group on Jobs and Growth, June 2012

111 BADIN, Michelle R. S. - A Regulação de "Novos Temas" em Acordos Preferenciais de Comércio Celebrados por União Europeia, Estados Unidos, China e Índia: Pontos Relevantes para o Brasil. IPEA, TD 1773, 2012 
services. The idea is to estimate the costs for the BRICS for not participating in a TTIP-type and a TPP-type agreements.

\section{Modeling hypothesis}

The GTAP computable general equilibrium model was used in the present simulations in order to evaluate the first round effects of the costs and opportunities for the BRICS of the conclusion of a TTIP-type and a TPP-type agreements.

The GTAP model is a global comparative static applied general equilibrium model. The model identifies 57 sectors in 153 regions of the world. Its system of equations is based on microeconomic foundations providing a detailed specification of household and perfect competitive firm behavior within individual regions and trade linkages between regions. In addition to trade flows, the GTAP model also recognizes global transportation costs.

The GTAP model qualifies as a Johansen-type model. This model estimates the impacts of external shocks (gains and losses of a PTA) through a comparative static modeling (before and after the shock). The solutions are obtained by solving the system of linearized equations of the model. A typical result shows the percentage change in the set of endogenous variables (GDP, exports and imports, exchange rate and land value) after a policy shock is carried out, compared to their values in the initial equilibrium, in a given environment.

The GTAP 8 database combines detailed bilateral trade, transport and protection data characterizing economic linkages among 129 regions, together with individual country input-output databases which account for inter-sectorial linkages within regions. The dataset is harmonized and completed with additional sources to provide the most accurate description of the world economy.

The main applied protection data used in the GTAP 8 database originates from ITC's MacMap database, which contains exhaustive informa- 
tion at the tariff line level. The ITC database includes the United Nations Conference on Trade and Development's (UNCTAD's) Trade Analysis and information system (TRAINS) database, to which ITC added their data. The model transforms all specific tariffs in ad valorem tariffs.

In order to capture the first round effects, the simulations were carried out using a standard GTAP hypothesis, which considers perfect factor mobility for labor and capital and imperfect factor mobility for land and natural resources. National aggregate supply of factors of production is exogenous and production technology for firms is given.

The way the economy variables are affected by horizontal reductions in bilateral import tariffs of the TTIP-type and TPP-type agreement partners will depend on the resulting behavior of domestic relative prices. Domestic relative prices of the TTIP-type and TPP-type partners will be altered in such a way that import competition from the PTA partner will be favored, as the economy becomes more preferentially open to trade. Overall efficiency in resource allocation tends to be improved and, by the same token, possible gains from trade may take national welfare a step up.

Notwithstanding the aggregate benefits from improved resource allocation, regions might be adversely affected by re-orientation of trade flows - trade diversion - as relative accessibility changes in the system. Thus, bilateral aggregate gains from trade are not necessarily accompanied by generalized regional gains in welfare. This issue of trade diversion versus trade creation has been an important one in the international trade literature, especially in the case of welfare evaluations of preferential trade agreements.

Three scenarios will be considered for the impacts of TTIP and TPP types on the growth rate and on the trade balance: a full tariff reduction between US and EU; a full tariff elimination plus a $50 \%$ reduction of non-tariff barriers (NTB); and a full elimination of both tariffs and NTBs.

For the modeling of the reduction of non-tariff barriers, this simulation used the results presented by the Ecorys Project (2009) developed 
by Berden e Francois to the European Commission. The Ecorys Project estimated, for the TTIP-type, the costs of non-tariff barriers for the US in relation to the EU and vice-versa. For the TPP-type, the present simulation uses the average of this two estimates as a proxy for the non-tariff barriers among TPP countries having the US and Japan as main partners.

\section{Results of the simulations}

A summary of the estimates for several scenarios are presented below.

\section{Effects of TTIP-type}

For each of the BRICS, the impacts of TTIP-type are calculated considering three different hypotheses: (i) a full tariff reduction between US and EU; (ii) a full tariff elimination plus a $50 \%$ reduction of non-tariff barriers (NTB); and (iii) a full elimination of both tariffs and NTBs.

The effects of TTIP on BRICS GDP growth and Trade Balance are the following:

Graphic I.1 - Impacts of TTIP-type on the BRICS GDP Growth (\%)

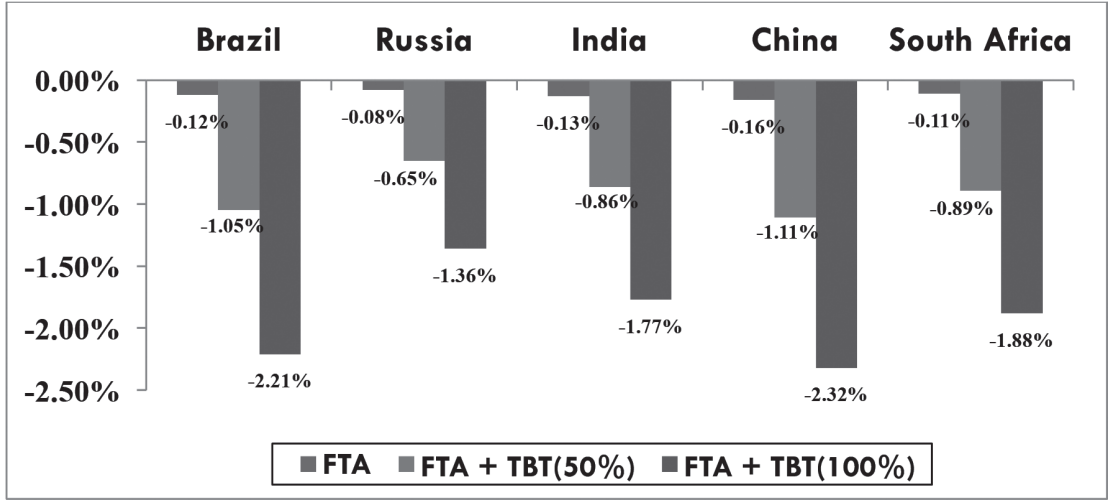

Source: CCGI (2014) 
Graphic I.2 - Impacts of TTIP-type on the BRICS Trade Balance (\%)

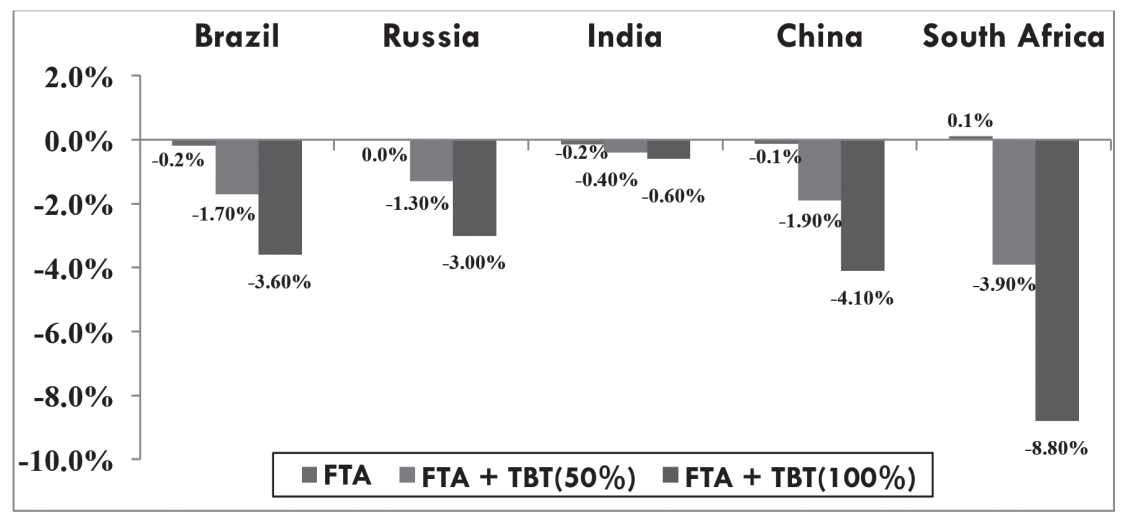

Source: CCGI (2014)

In economic terms, with the negotiation of TTIP type, all BRICS will suffer losses in their growth rate and trade balance, considering the first round effects presented by the simulation and comparing the costs by each of the five countries with this agreement. It is possible to assume that the TTIP-type will result in gains of competitiveness for its partners while the BRICS, by remaining outside of the agreement, could suffer further losses in their trade balance.

When only the reduction of tariffs is considered, the results are not expressive. However, when the elimination of non-tariff barriers between EU and US are considered in the hypothesis of 50\% and 100\%, the negative impacts are significant, regarding sectorial GDP and trade flows. More than tariffs, the trade gains of TTIP-type will be obtained through negotiations of non-tariff barriers including technical barriers, sanitary and phytosanitary measures, trade facilitation, among others, which are, nowadays, the real barriers to trade. 


\section{Effects of TPP-type reformulated in bilateral PTAs}

This simulation presents the impacts of a TPP-type reformulated in bilaterals to the BRICS economies, considering: (i) a full tariff liberalization amongst TPP-type members; (ii) a full tariff liberalization plus a $50 \%$ reduction of non-tariff barriers (NTB) amongst TPP-type members; (iii) a full tariff liberalization plus a $100 \%$ reduction of non-tariff barriers (NTB) amongst TPP-type members.

The effects of TPP-type on BRICS GDP growth and Trade Balance are the following:

Graphic I.3 - Impacts of TPP-type on the BRICS Growth (\%)

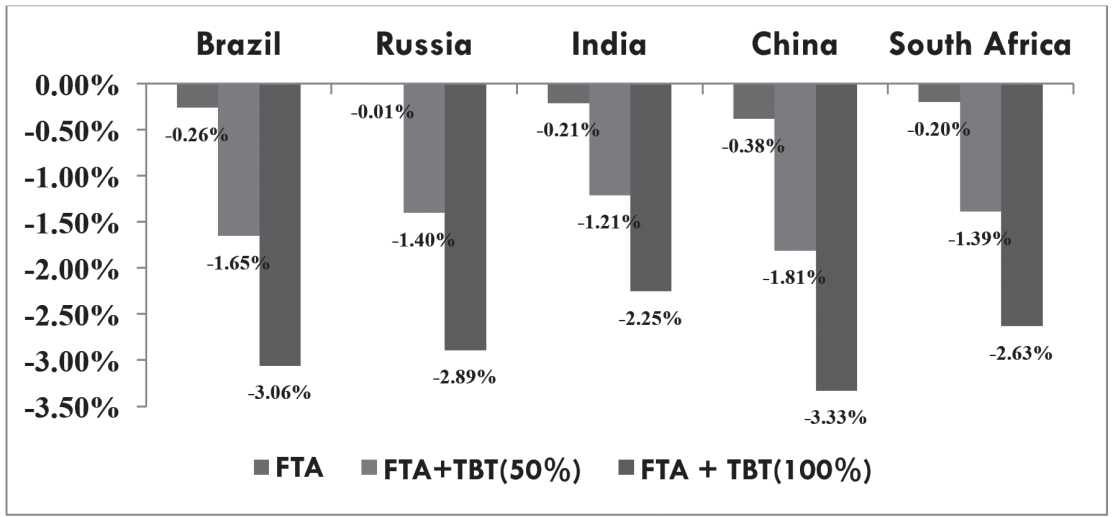

Source: CCGI (2014) 
Graphic I.4 - Impacts of TPP-type on the BRICS Trade Balance (\%)

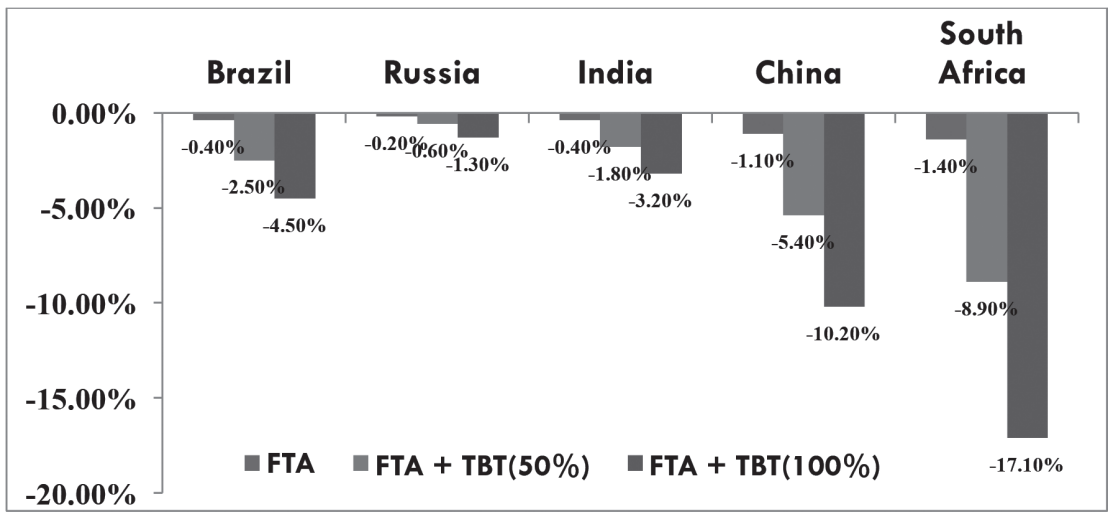

Source: CCGI (2014)

As the TTIP-type agreement, the TPP-type agreement shall present negative impacts for the BRICS economies already in the first round effects. These impacts can be more significant with the gains of competitiveness of the TPP-type agreement partners, as the result of the agreement.

When only the reduction of tariffs is considered, the results are not expressive. However, when the elimination of non-tariff barriers between TPP-type partners are considered in the hypothesis of 50\% and 100\%, the negative impacts are significant, regarding sectorial GDP and trade flows. More than tariffs, the trade gains of TPP-type will be obtained through negotiations of non-tariff barriers including technical barriers, sanitary and phytosanitary measures, trade facilitation, among others, the new barriers to trade.

\section{Conclusions}

The new generation of PTAs, TTIP-type or TPP-type agreements, when concluded, will promote a deep economic integration within its members, which should result in the elimination of several trade barriers, regulatory coherence and convergence through harmonization or regulatory 
equivalence, and creation of regional value chains. The benefits of this deep integration include an increase in business opportunities (trade in goods and services and investments) amongst the partners as well as the exchange of know-how and technology through the internationalized production chain, enhancing the countries' competitiveness.

However, the formation of these new generation agreement will affect negatively trade partners that do not participate in this process of regional integration. When tariff and non-tariff barriers are considered, the negative effects on some outsiders, such as each of the BRICS, will be significant, not only in terms of growth but also in terms of trade balance.

Facing the reality of the multilateral trading system with the crises of the WTO and the multiplication of a new generation of PTAs, the excluded countries, encompassing emerging, developing and least developed countries, will have to rethink their strategies related to trade policies.

- They can follow passively the negotiation and implementation of these new generation of PTAs. The consequence is that these new rules will be imposed to the excluded countries and they will need to adapt and follow several of the requirements present in these agreements without having participated in the drafting of such rules, and thus, without being able to negotiate its own interests and perspectives in the regulation of such themes. Therefore, becoming rule takers, instead of rule makers, and bearing all the costs related to their late arrival in the new generation of international trade rules.

- They can accept the new reality and decide to negotiate their accession to these new blocs, as soon as the first generation of agreements is achieved. There will be a short space to negotiate their interests since the degree of freedom will be smaller. This option will represent the incorporation of the new models of trade under the assumption that participating in the benefits will compensate for the costs of adaptation.

- They can decide to leverage the only forum that has a multilateral character - the WTO. The impulse for the creation of these generation of agreements can have two reasons. One is that the EU and the US, 
after many years, understood that they could not impose their interests upon the emerging countries and decided to go to another track for their trade policies. The other is that they decided to create new rules to impose to the others, having as objective the transformation of the WTO in a weak organization. The only solution is for all the excluded countries to return to the WTO and make a last effort to close the Doha Round in exchange of a new multilateral round with all the important new issues included in the negotiation.

The new paradigm of the World, however, asks for a profound reform of the WTO, not only the decision process by consensus, as a new geometry for agreements as plurilaterals and multilaterals, and new forms for trade rules for developing countries.

\section{GLOBAL VALUE CHAINS}

\section{Introduction: the paradigm of global value chains}

The International Trading System is incorporating a new paradigm in the production of goods and services - the paradigm of the of global value chains. The intensification of this model in the production system is forcing trade experts to reconsider many rules of trade regulation and also to defend this model as the new vector of integration for developing countries in international trade. OECD, IMF, World Bank and WTO are investing great efforts in the analysis of the impacts of these global chains.

Numerous definitions are being proposed in order to characterize global value chains. A chain can be identified as a set of activities required to produce and deliver a product to the final consumer, including services carried out prior to production as R\&D, software, design, branding, financing, activities of system integration, as well as post-production services such as logistics and after-sales services. There are producer-driven 
chains for high-tech products based on capital, but also consumer-driven chains that for mass products based on lower wages.

The qualification of a given process as a global value chain comes from the fact that production takes place in stages that add value to products. At each stage, the producer acquires its inputs and employs production factors. The payment of these factors will set the value added to the product. The process is repeated at the next stage so that the former becomes the value added cost to the next producer. The set of steps may be performed by one or several companies within and outside the country, creating a production chain.

The recent interest in the new production paradigm has taken place because trade flows arising from the outsourcing of production stages are intensifying. Such flows occur mainly between developed and developing countries, creating growth opportunities. This new relationship has been beneficial to developing countries, as it is observed with the increase of the income share of world exports acquired by such countries. The causes that allowed the emergence of these flows are the drastic reduction of transport and communication costs, the significant increase in foreign investments and the liberalization of international trade ${ }^{112}$.

In this new scenario of world trade, new issues are being raised by countries that wish to increase their participation in international trade. Among the concerns raised, one can identify issues related to a more competitive export policy that depend on the efficient supply of inputs; to have access to producers and consumers; and the specialization of countries with higher concentration on tasks and business functions rather than on individual products ${ }^{113}$.

112 BACKER, K. De; MIROUDOT, S. - Mapping Global Value Chains, OECD Trade Policy Papers, No. 159, 2013. BALDWIN, R.E.; LOPEZ GONZALEZ, J. - Supply-Chain Trade: A Portrait of Global Patterns and Several Testable Hypotheses, NBER Working Paper 18957, 2013.

113 BACKER; MIROUDOT - op. cit. 
Thus, there is a direct impact of global value chains on the formulation of trade, industrial, and macroeconomic policies. The expansion of global chains in world trade creates challenges for the usual trade statistics, since the chains accentuate problems inherent to the usual ways of measuring trade flows and require the estimation of other measures in a way that can fully understand the productive model. It creates new concepts such as "trade in tasks" against the former "trade in goods".

The interest in the model grows as trade patterns change since the flows arising from the chains have been occupying a significant portion of world trade. Such trade flows have occurred mostly among high-tech nations from the North, but also with low-wage countries of the South. The new trade flows have become more significant, especially for those countries in the vicinity of major industrial economies in the World such as USA, Germany, Japan and China, which highlights the fact that the chains have a distinctly regional character. Finally, it is noteworthy that these new business relationships were not restricted to a greater flow of goods between the borders of countries, but also have an increased international mobility of administrative and productive knowledge. Foreign firms take to the countries of assembly not only the parts to be assembled, but also the knowledge on how to assemble them, how to manage the assembling firms and how to deliver the product manufactured.

Some unique characteristics of the chains explain the recent global economy. The first is the increasing fragmentation of production and consequent increase in the interdependence of countries. This happens because export competitiveness now lies in the efficient provision of inputs, as well as on the access to final producer and foreign consumers. The second is the fact that the specialization of countries has happened more in tasks and business functions rather than on individual products. Now, the relevant competition of a country is not between the domestic products against the foreign products, but rather related to which roles they play in the value chain. The third is the new global governance structure. The analysis of global value chains allows the understanding 
of which firms and which countries control and coordinate production activities along a chain.

International trade policies face yet another challenge: the fact that the importance of the chains in international trade highlights problems in the usual trade data, as the double counting problem and the potential overestimation of the importance of exports / imports in GDP; the distortion of the importance of imports and exports on economic growth and income; and the difficulty of understanding the actual weight of trade relations between countries and the real importance of services to trade.

Due to the global value chains, trade occurs mainly through intermediate goods, ie, goods that are inputs in the production process of other nations. Therefore, to explain the importance of the chains is imperative to identify the flows of these intermediate goods. ${ }^{114}$ However, such information is not directly available in trade databases. In order to get such information is necessary to resort to detailed customs classifications or use input-output tables that track the use flows, or even use data from processing trade available for some nations with special customs regimes.

The global value chains model has substantial impacts on the formulation of national policies. The following points may be highlighted:115

The identification of partners truly responsible for the trade balance;

The reduction of trade disputes by explaining that trade barriers can impact domestic products;

The increasing importance of macroeconomic shocks reproduction across countries because they are magnified in the presence of global value chains;

The importance given to low-skilled jobs import, as these imports can generate net increase of job openings, as well as expertise in works demanding a higher qualification;

114 BALDWIN; LOPEZ GONZALEZ - op. cit.

115 BALDWIN; LOPEZ GONZALEZ - op. cit. 
The importance of certain countries in world industrial production, since the comparative advantages of countries are more associated to tasks performed along the chain instead of the exported products.

\section{Trade in value added and global value chains}

Over the decades of 1970 and 1980, global value chains were already evident in the rise and rapid industrialization of many Asian countries, including China and Southeast Asia. Regarding international trade, what is important to these countries is the way they decided to open their trade, based on fragmentation and specialization of production stages. By integrating their chains both in North America and Europe, and also building its own regional value chain, these Asian countries gained greater importance in world trade. More recently, Eastern European countries such as Poland, Czech Republic, and Hungary also became examples of areas which opted for a greater share in productive specialization. The intra-industry trade, once established among more developed countries, today is a major constant in trade relations around the globe, constituting more than two-thirds of all world trade.

Two points are important to consider about the logic of global value chains: the geographical proximity and the demands underpinning integration. Regarding the first point, it is undeniable that geographical proximity matters for the formation of global value chains ${ }^{116}$. However, increasingly, the reduction of transport costs and advances in communication technologies provide a global character to the chains ${ }^{117}$. For the second point, it should be considered that participation in the chain requires coordination, agility in the production and transaction facilities.

116 JOHNSON, R.; NOGUERA, G. - Fragmentation and Trade in Value Added Over Four Decades, NBER Working Paper No. 18186, 2012. JOHNSON, R. C.; NOGUERA, G., -"Accounting for Intermediates: Production Sharing and Trade in Value Added", Journal of International Economics, 86, 2012, pp. 224-236.

117 BALDWIN; LOPEZ GONZALEZ - op.cit. 
Such demands show not only the importance of reducing tariff barriers as well as non-tariff ones, including rules of origin, technical, sanitary and phytosanitary barriers, but also the need for good infrastructure conditions therein including logistics and skilled workforce, with also a good business environment ${ }^{118}$.

It is important to emphasize that according to the logic of global chains, a country that imports little and exports only domestically produced goods without inputs, parts or pieces from other countries, will be out of the integration of chains and removed from the gains perceived from the globalized chains. For such countries, the trade logic shifts from a protectionist logic to an open market logic, where tariffs, antidumping and rules of origin are not considered because they represent border costs.

In short, the trade of intermediate goods must represent a significant portion of world trade. One implication of this productive fragmentation is that there must be more foreign content in domestic exports, which means less domestic value added for each dollar that is exported ${ }^{119}$.

\section{BRIC and the global value chains ${ }^{120}$}

Once the logic of trade in value added is made clear, one can question the present level of integration of emerging countries in the value chains.

Regarding the BRIC, the Graphic below, although not conclusive, shows evidence that China and India are in a better position than Brazil and Russia regarding these chains, since they use a smaller amount

118 TIMMER, M.P.; LOS, B.; STEHRER, R. and VRIES, G.J. de - "Fragmentation, incomes and jobs. An analysis of European competitiveness". Economic Policy, 28, 2013, pp. 613-661.

119 JOHNSON; NOGUERA -, Fragmentation and Trade in Value Added Over Four Decade.

120 The results and methodology for these estimations results are explained in FERRAZ, L.; GUTIERRE, L.; CABRAL, R. - A indústria brasileira na era das Cadeias Globais de Valor, CCGI, EAESP-FGV, 2014. (ccgi.fgv.br). 
of foreign content in their exports when compared to other countries in the globe. Despite the low value added per dollar exported, what is happening is that China is a country that has benefited the most from the model of global value chains.

\section{Graphic II.1 - Comparative framework of foreign content in manufacturing exports (1995-2011)}

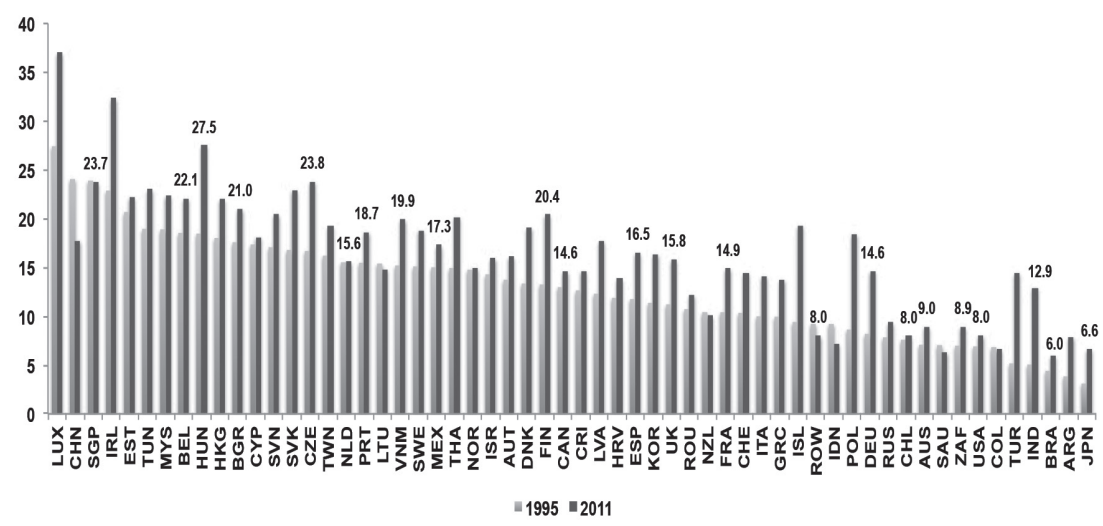

Source: OECD - WTO

The rationale of global value chains requires a different interpretation for foreign trade and for the issue of value added. This is because traditional trade statistics on a gross basis cannot measure, in the right way, some characteristics of the contemporary international trade.

The following Graphic shows the development of BRICS share of world exports regarding value added. The performance of China concerning value added places the country in a prominent position in relation to other partners. 
Graphic II. 2 - BRIC share of world exports regarding value added

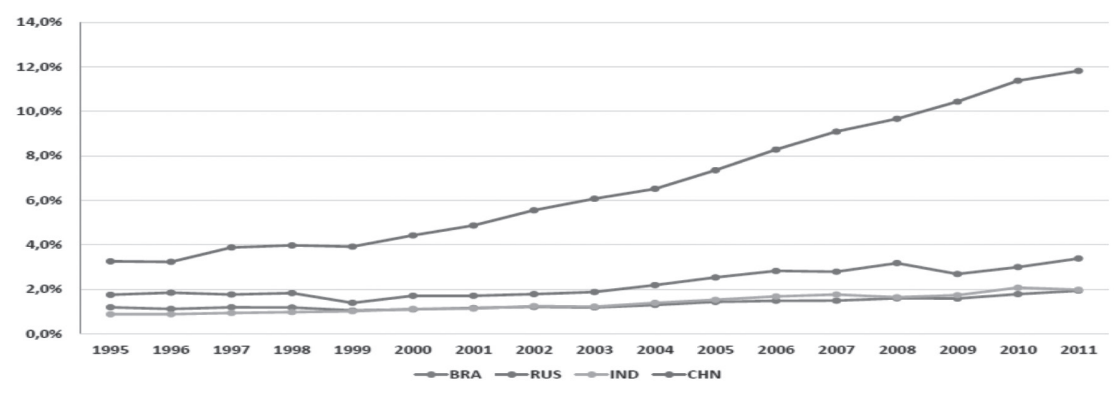

Source: WIOD, CCGI-EESP-FGV calculations

\section{Exports and imports of intermediate products}

Concerning the trade of intermediate products, the index of intermediate imports to GDP and the ratio of intermediate exports to GDP allow the comparison of the degree of integration of a given country into global value chains. According to the Graphic below, it is possible to assume that Brazil, when compared to several other countries, has the lowest percentage.

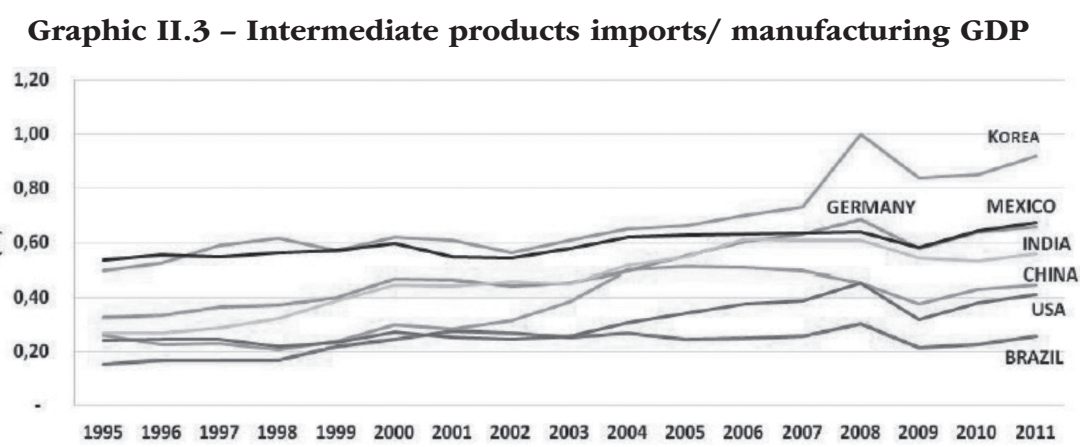

Source: WIOD, CCGI-EESP-FGV calculations 


\section{Graphic II. 4 - Intermediate products exports/ manufacturing GDP}

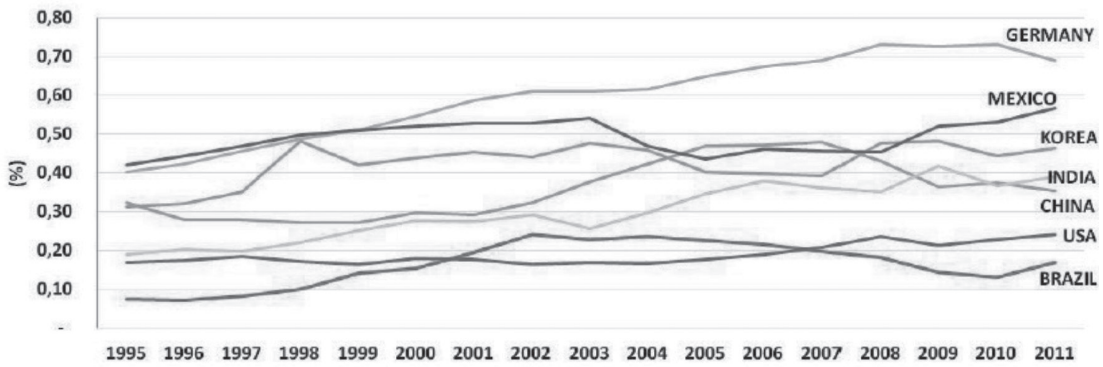

Source: WIOD, CCGI-EESP-FGV calculations

As a result, in the case of Brazil, despite a slight decrease over the period, the share of domestic inputs in the total consumption of inputs by the Brazilian industrial sector is still far above the rates observed in many emerging and developed countries more integrated in the value chains.

\section{Graphic II.5 - Share of domestic inputs in the total consumption of} inputs by the industrial sector

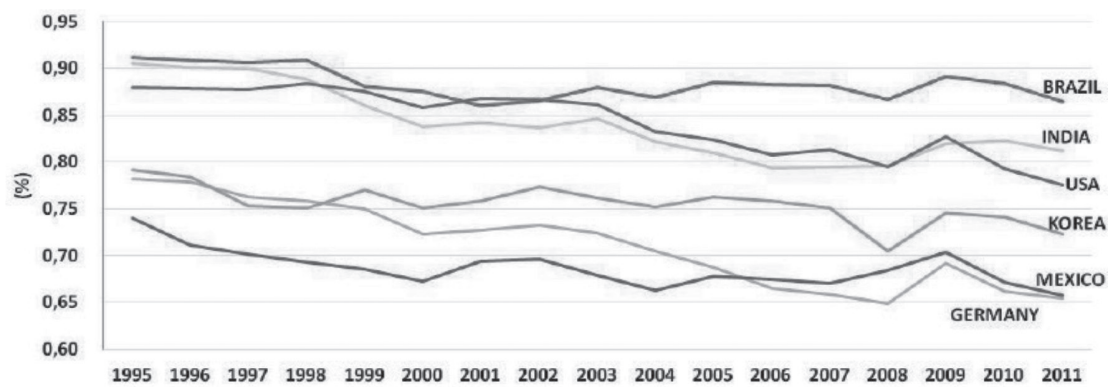

Fonte: WIOD, CCGI-EESP-FGV calculations 


\section{Conclusion}

The evidence analyzed above points to the low level of integration of the Brazilian economy regarding global value chains. This is also happening with several other emerging countries. In order to guarantee their integration, it will be necessary to rethink their trade policies towards new industrial policies aiming to achieve greater competitiveness for their national industries. It can be argued that there are two main options open for these emerging countries not yet integrated.

On the one hand, these countries could conduct unilateral inclusion policy with the adoption of an open trade regime by reducing tariffs, increasing flexibility in rules of origin and reducing trade protection via antidumping, with financing and tax incentives in the search for technological innovation. On the other hand, it is also possible to adopt a policy of negotiating preferential trade agreements with countries that complement such insertion, via reduction of tariffs, coordinated rules of origin, and importation of higher-tech components and technology transfer.

Another important point that deserves to be addressed is whether the priority for those non-integrated countries to look for regional integration in their own geographic area. In the case of Brazil, the question is whether Brazil should seek regional integration in South America or

global integration with more developed countries such as Europe, the US, and even China. The phenomenon of global value chains has a strong regional nature due to shipping costs. However, the need to seek greater technological value content creates a significant limitation for regional expansion to these non-integrated countries.

All the logic of global value chains should be taken into account when emerging countries discuss their trade policy and whether and how they intend to be integrated into global chains changes. The logic of global value chains is significantly affecting the logic of their international trade policies and the same is true for the inverse. 


\section{III - REGULATORY BARRIERS, MARKET STANDARS AND THE RISE OF THE CONSUMERS INTERESTS}

\section{Introduction - a regulatory war of the Global North against the Global South}

The Trading System is facing a new challenge with the multiplication of rules that affects not only the trade of goods and services but also the production methods, labor standards, and the impact on the environment and climate. Important trade regulations also encompass many other rules such as customs measures, investment, and competition rules, not to mention energy, emissions, animal welfare, and geographic indication. More than tariff barriers, trade is being affected by the widespread imposition of regulations, standards and certifications, and detailed labeling about the origin of inputs, methods of production, and impacts on sustainability of every product.

Regulatory measures are being used to differentiate products. They can appear in technical regulations (mandatory) and standards (non-mandatory) for industrial products, sanitary and phitosanitary measures to food, voluntary standards related to labor, and voluntary or mandatory standards related to sustainability of production.

They can be created by national governments or international governmental organizations as international standards. They can be negotiated by international private associations as international private standards and incorporated by governments. They can also be created by the market through transnational enterprises imposing standards on their value chain, by non-governmental organizations or consumers associations as "voluntary" standards.

The main problem of this regulatory cacophony is that each rule creates its own regulation, standard, and certification. They can be created by several different entities as private sectors, associations, transnatio- 
nals, and governments. They can be mandatory or voluntary, or can be imposed by the coordinators of the production chains.

The multiplication of these standards is also imposing new rules in the preferential trade agreements. The result is the creation of three types of governance: one is the regulatory coherence among domestic bodies inside the country; other is the regulatory convergence to be negotiated among partners of the same trade agreement, involving the discussion of different methodologies of work as harmonization or equivalence of standards. When countries of different level of development are interacting, a third type of governance is created, that of regulatory cooperation.

There is an important issue behind all this variety of standards in international trade. The great majority of this government or non-governmental, private or market, national or international regulations are being created by developed countries under the pressure of their consumers, conscientious with the future of the Planet. Developing and more especially emerging countries are also aware of the main problems concerning sustainability. However, they are in another level of development. Trade is an important component of their economies and the developed World is an important market for their exports. What developing countries are facing now is the multiplication of new barriers to their products.

In international trade, the multiplicity of regulations, standards and certifications can be transformed in trade barriers much more significant that the old tariff barriers. Certainly they are the new 21st Century model of trade barriers, a new divide between the Global North and the Global South. There is an urgent need to put some order on this regulatory chaos. It is time to the main actors negotiate some international rules to transform these standards in instrument of development not of a new division among countries. 


\section{Multilateral rules on regulation and standards}

GATT and WTO have recognized the importance of negotiating rules for these regulations and standards. The WTO Technical Barriers to Trade (TBT) and Sanitary and Phytosanitary (SPS) Agreements aim at ruling, on a multilateral level, over measures that are created to protect human, animal or plant life or health, or the environment.

Having the history of the creation of these rules in mind is relevant. Since 1948, with the creation of the GATT, the negotiations focused on tariff barriers. In 1979, after eight rounds of negotiations, the Standards Code came into existence and was signed by 43 contracting parties in the Tokyo Round. In this Round, there was a first major attempt to negotiate non-tariff barriers. The Standards Code dealt with mandatory and voluntary technical specifications, mandatory technical regulations, and voluntary standards for industrial and agricultural goods. It also covered technical requirements related to food safety and animal and plant health measures, including inspection requirements, labeling and pesticide residue limits. Relevant international standards were agreed to be used by the 1979 Standards Code signatories, except when they were not adequate to protect health. That was the launch of the principle of harmonization for non-tariff barriers in the multilateral system ${ }^{121}$.

Most of the signatories agreed that the Standards Code failed to deal with trade of agricultural products and that there was an increase in technical restrictions. Therefore, in 1995, in the end of the Uruguay round, the TBT and the SPS came into force as separate multilateral agreements under the auspices of the just born World Trade Organization. TBT and SPS measures have grown sharply since the 1990s and have become the main substitutes of tariff barriers in the world scenario.

121 GRIFFIN, R. - "History of the Development of the SPS Agreement". In: FAO Documents, Multilateral Trade negotiations on Agriculture - a resource manual, Rome, 2000. http://www.fao.org/docrep/003/x7354e/x7354e01.htm (Access on 16 June 2014) 
Graphic III.1 - Increase of TBT measures (1997-2013)

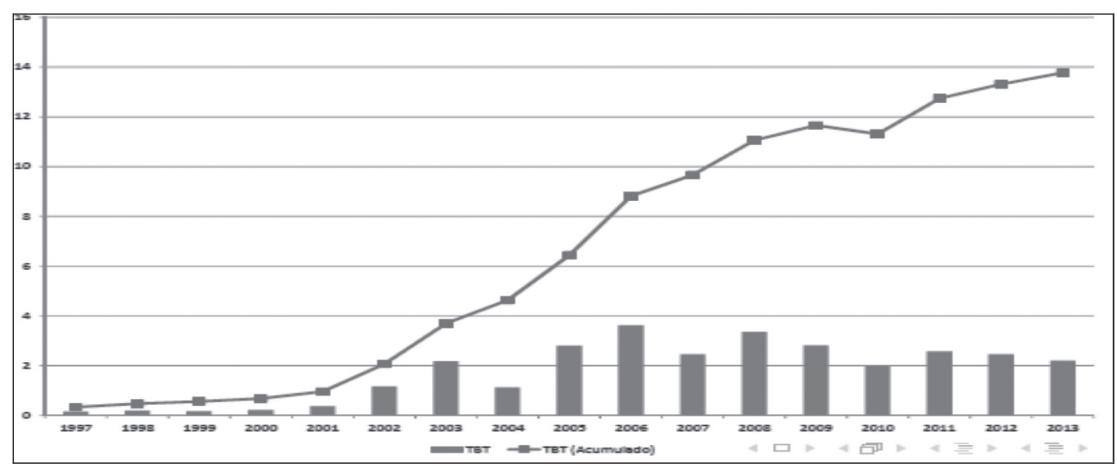

Source: WTO, CCGI- FGV, 2014

Graphic III.2 - Increase of SPS measures (1997-2013)

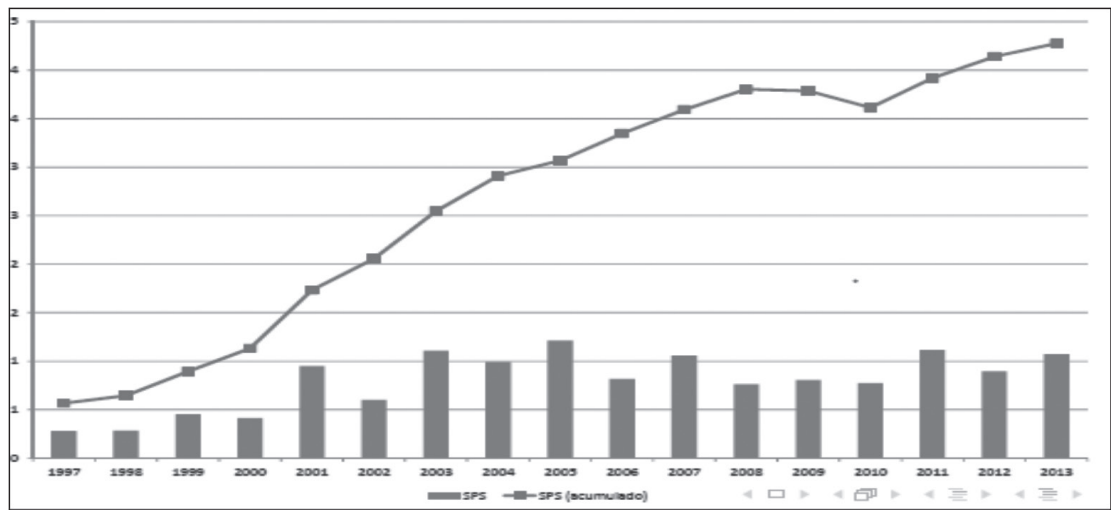

Source: WTO, CCGI- FGV, 2014

TBT and SPS complement Article XX of GATT that established the rules of exception to the GATT. Both try to identify how to meet the need to apply rules concerned with health and environment and, at the same time, avoid protectionism in disguise. In the Uruguay Round, it was not possible to amend Article XX of GATT. Some of the agreements negotiated in that Round - for instance, TBT and SPS - represented 'interpretation notes' of the rules enshrined in the exceptions of Article XX. 
The TBT and SPS Committees in the WTO have been a discussion forum for specific trade concerns (STCs), which have served, by large, as a conciliation forum, avoiding disputes under the Dispute Settlement Mechanism of the WTO.

In synthesis, it is important to note that TBT and SPS have a common origin - the Tokyo Round Standards Code and that TBT and SPS are extensions of Article XX of GATT, the main article on exceptions in the GATT/WTO context. However, under the pressure of transnationals, private bodies, and consumer associations, new types of standards were created, and the simple division between measures of TBT or SPS cannot be sustained. In practice, the surge of market and private standards is complementing this gap.

\section{Private, Market and Voluntary Standards}

In the last decades, many have discussed the impacts of globalization and the spread of a new phenomenon that comes with it - global governance, which means multiplication of international actors, proliferation of distinct norms, and manifestation of different concerns from such a multiplicity of regulators and regulation.

Multilateral and governmental initiatives have been incapable of addressing these global challenges that have spread with the emergence of new non-state market regulatory initiatives, which are aimed at governing production, production process, and supply chains across the globe according to a set of non-governmental private standards, rules that regard different and complex issues, such as food safety, environmental protection, labor conditions, human rights protection, and others ${ }^{122}$.

There are many arguments for and against private standards, but none of them can ignore the fact that these standards have become a reality

122 MARX, A.; MAERTENS, M.; SWINNEN, J. and WOUTERS, J. - Private standards and global governance. Leuven Global Governance Series. Edward Elgar Publishing, 2012. 
on global trade. Therefore, it is urgent the need to better understand and analyze the institute of private standards, in order to maximize their positive points and minimize their negative ones, overcoming policy inertia as well as market failures.

Pascal Liu presents private standards as standards that are elaborated by non-governmental entities, which belong to them, whether they are profit-oriented (private companies) or non-profitable bodies ${ }^{123}$.

The following table offers a list of private standards.

Table III.1: Examples of private standards

\begin{tabular}{|l|l|l|}
\hline $\begin{array}{c}\text { Created by Individual } \\
\text { companies }\end{array}$ & \multicolumn{1}{|c|}{$\begin{array}{c}\text { Created by national } \\
\text { chains }\end{array}$} & \multicolumn{1}{|c|}{$\begin{array}{c}\text { Created by } \\
\text { international chains }\end{array}$} \\
\hline $\begin{array}{l}\text { Nature's Choice } \\
\text { (TESCO) }\end{array}$ & $\begin{array}{l}\text { Assured Food } \\
\text { Standards (UK) }\end{array}$ & GlobalGAP \\
\hline $\begin{array}{l}\text { Filiéres Qualité } \\
\text { (Carrefour) }\end{array}$ & $\begin{array}{l}\text { British Retail } \\
\text { Consortium Global } \\
\text { Standard }\end{array}$ & $\begin{array}{l}\text { International Food } \\
\text { Standard }\end{array}$ \\
\hline $\begin{array}{l}\text { Field-to-Fork (marks \& } \\
\text { Spencer) }\end{array}$ & Freedom Food (UK) & $\begin{array}{l}\text { Safe Qaulity Food } \\
\text { (SQF) 1000/2000 }\end{array}$ \\
\hline $\begin{array}{l}\text { Filiére Controllée } \\
\text { (Auchan) }\end{array}$ & $\begin{array}{l}\text { Qualitat Sicherheit } \\
\text { (QS) }\end{array}$ & $\begin{array}{l}\text { Marine Stewardship } \\
\text { Council (MSC) }\end{array}$ \\
\hline $\begin{array}{l}\text { P.Q.C. (Percorso } \\
\text { Qualitá Conad) }\end{array}$ & $\begin{array}{l}\text { Assured Combinable } \\
\text { Crops Scheme (UK) }\end{array}$ & $\begin{array}{l}\text { Forest Stewardship } \\
\text { Council (FSC) }\end{array}$ \\
\hline $\begin{array}{l}\text { Albert Heijn BV: AH } \\
\text { Excellent }\end{array}$ & $\begin{array}{l}\text { Farm Assured British } \\
\text { Beef and Lamb }\end{array}$ & \\
\hline & Sachsen Ahrenwort & \\
\hline QC Emilia Romagna & $\begin{array}{l}\text { Stichting } \\
\text { Streekproduction } \\
\text { Vlaams Brabant }\end{array}$ & \\
\hline & & \\
\hline
\end{tabular}

Source: WTO, SPS Committee

123 LIU, P. - "Private Standards in International Trade: Issues and Opportunities", WTO's Workshop on Environment-related Private Standards, Certification and Labelling Requirements, Geneva, 9 July 2009, p.2. 
In general, private standards have faced many concerns and have become a big challenge for the multilateral trade system. Some of the challenges that international trade governance has faced with private standards may be listed as such:

i) multiplicity of interoperability of private standards, which implies lack of harmonization and equivalence on similar standards, including compliance costs, since there are multiple standards for a single product;

ii) marginalization of small holders and developing and least developed countries due to complex, rigorous and multi-dimension standards;

iii) concerns that private standards undermine the structure of the WTO Agreements on Technical Barriers to Trade (TBT) and Sanitary and Phytossanitary Measures (SPS);

iv) risk that private standards are disguised and arbitrary measures that undermine all the globalized structure of free trade;

v) multiplication of private standards that may put at risk their sustainability objectives and create confusion to producers and consumers ('green-washing');

vi) lack of a multi-dimensional approach on addressing risks for the composition of private standards since many of the standards set are not science-based;

vii) effects of many private standards that are part of global supply chains, which generates concerns on national policies and priorities and respect to natural trade intensity of exporting countries ${ }^{124}$.

${ }^{124}$ UNFSS Forum on Sustainability Standards, Geneva, 2013. Documents available at www.unfss.org (Access on 2 February 2015). 
The following graphics illustrate the numbers and origin of private standards.

Graphic III.3 - Private standards - number of certifications

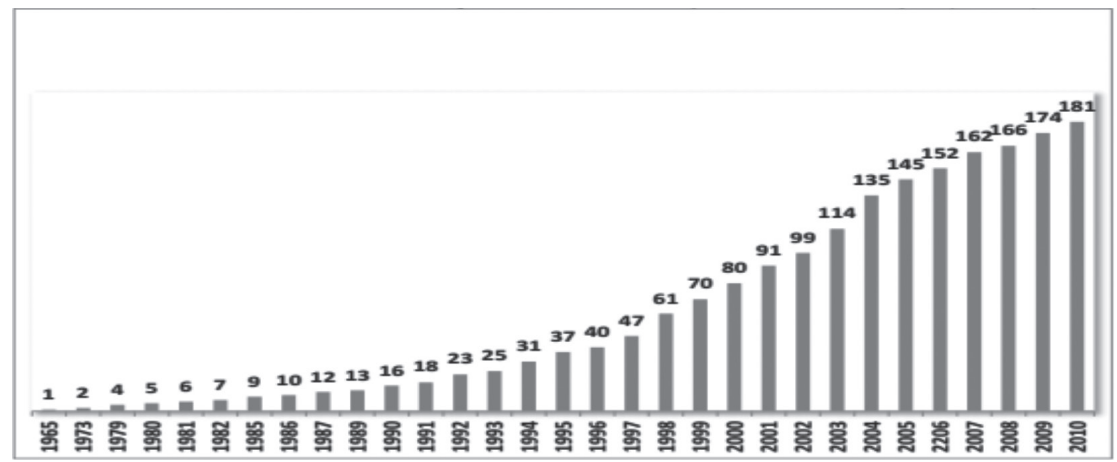

Source: European Commission.

Graphic III.4 - Private standards - certifications by origin

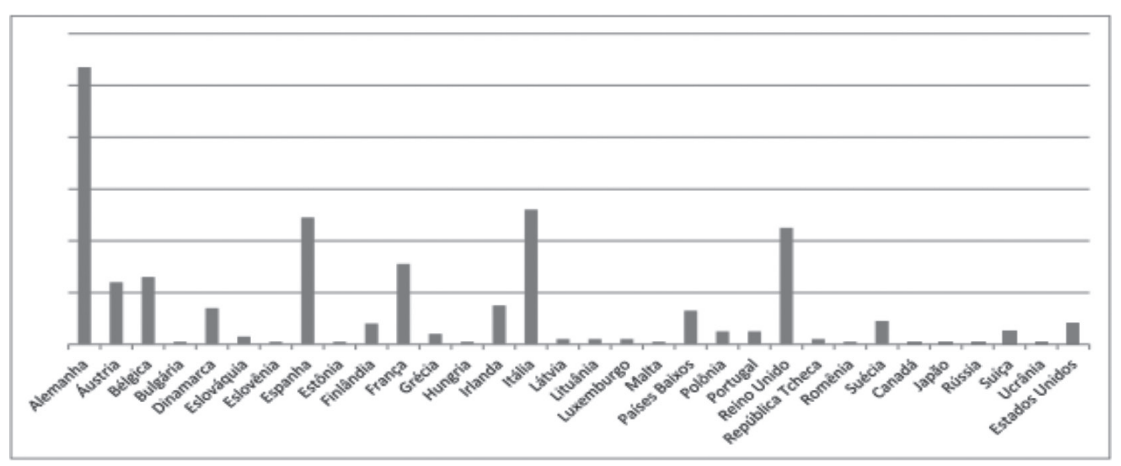

Source: European Commission.

In summary, all the concerns herein expressed are related to three main issues: legitimacy, accountability and trade barriers.

Concerns related to legitimacy intend to answer questions such as: i) 'who is producing the standards?' and ii) 'where such authority comes from?' 
Concerns related to accountability are related to: i) are there scientific basis for the creation of such standards?; ii) who responds for the setting of private standards under a market/government failure and a Multilateral Trading System perspective?

\section{Some points to be clarified about private standards}

To give answers to these concerns, the discussion among the main players in this area could be concentrated in the following points.

The first point is terminology. There is a need of a new identification for private standards with the purpose of differentiating them from other well stablished international private standards such the ones developed by ISO - International Standards Organization. Some proposals are Market Standards, or Non-Governmental Standards. Although the definition of 'private standard' in itself is not a pacific one, it must be taken into consideration that private standards may be considered 'international standards' and their 'non-governmental character' does not exclude them from the multilateral trade system; instead they might be well accommodated within the TBT and SPS Agreements. Private standards have been considered voluntary in nature, but they are de facto mandatory and whenever they are backed by governments, they might fall within the scrutiny of the TBT and SPS Agreements and Committees.

The second point is related to the creation of a meta-regulation in order to deal with the overall problems associated with the proliferation of private standards and to deal with their complexity. It is important that a meta-structure for these private standards be created, in order to develop basic principles, rules and instruments for the establishment, compliance, supervision and conflict resolution of such standards. The proliferation of market standards has brought big challenges towards legitimacy on creation and setting of such standards as well as accountability and State responsibility towards the behavior of the bodies 
that have issued them. Meta-regulation would be the key to calm down concerns related to private standards.

Some aspects of this meta-regulation effort have been on-going, split in different sectors and strategic areas. In general, so far, the existent meta-governance efforts have taken the structure of 'an internally oriented collaboration between a limited number of like-minded peers active in the same sector, an inclusive process aiming to bring and influence as large as possible a subset of standards initiatives and other stakeholders in a particular industry, and a collaboration between frontrunners from a variety of different fields'125. In the end, their poor efficiency, as pointed out by distinct scholars, is also related to legitimacy and accountability, since they do not diminish the overall problem of proliferation of standards, 'standardization of standards', and general confusion among producers and consumers, letting the market free to decide what it wants to do.

The third point is related to the necessity of the creation of an international body on private standards, which will bear responsibility for the negotiation of basic rules as well as for the representation of their stakeholders in the international trade forum - the WTO - the meta-organization in charge of trade regulation - and its landmark agreements on TBT and SPS measures. Perhaps, a multilateral stakeholder structure, such as ISO or UNFSS would gather together a larger number of stakeholders and could have more legitimacy on the setting of meta-regulation on market standards, which could diminish the problems of 'greenwashing', anti-competitive practices and malpractices in the standards setting activities.

One of the biggest challenges would be the choice between a model of meta-regulation based on a 'secretariat' or based on 'membership'126. A membership model - such as the one established by ISO - would ge-

125 DERKX, Boudewijn - Meta-governance in the Realm of Voluntary Sustainability Standards: Early Experiences and Their Implications. UNFSS Discussion Papers No. 1, 2003, p. 15.

126 DERKX - op. cit., p. 21. 
nerate more support for the meta-governance process among member organizations and States and perhaps would lead more easily to a plurilateral or multilateral collaboration. On the other hand, a model based on secretariat, such as the one created by the UNFSS, would have more autonomy and as such could lead to a process of meta-regulation that operates faster, more decisively and more productively. One should not forget that, in the end, the goal is to achieve effectiveness.

ISO has been stigmatized by some non-government bodies as a club dominated by private industrial groups, where civil society has no real role to play. ISO members are national standards bodies, many of which in turn are private non-profit groups, often dominated by private companies. Not only is civil society excluded from the decision-making process - it may not even exercise a critical role, as proposed standards are difficult to access. Even adopted ISO standards cannot be accessed free of charge but must be purchased. Such legitimacy and accountability issues may present some challenges for the ISO to represent market standards stakeholders at the WTO.

Due to 'their global reach, extensive expertise, strong legitimacy, perceived neutrality and ability to act as a gateway to more government involvement, UN agencies are particularly well-positioned to successfully take up such a meta-governance role (...) UN involvement would also be beneficial when it concerns the meta-governance of exclusively private standards setting fields' ${ }^{\prime 27}$. Thus the UNFSS could be well positioned in taking up such a role. In fact, under the auspices of the UNFSS, national platforms have been built in China and in India, which purport to become UNFSS focal points in order to coordinate between standardization composed of public/private sector, and policymakers, thus establishing a feedback system that would build on a whole scenario for private standards.

Significant work of some private bodies such as ISO, IEC and UNFSS and the main private standards platforms also have to take into conside-

127 DERKX - op. cit., p. 19. 
ration the work of several governmental bodies such as Codex and OIE. The complexity of global trade demands that some basic rules, such as transparency, non-discrimination, accountability, supervision, must be negotiated within these new set of standards.

The fourth point is where to discuss private standards and where set the rules against trade discrimination. WTO is certainly the right place. Some discussion started already at the WTO in 2005, but it is mainly considered in the SPS Committee. This discussion was not included in the agenda of the TBT Committee because of the blocking attitude of the developed countries. This was a big misconception, since private and market standards are, par excellence, standards related to sustainability and consumer protection under the TBT Committee.

The multiplication of regulatory systems is a reality of the international trade. Whether they will become a trade barrier or not is a matter to be discussed and negotiated in the preferential and multilateral fora. Facing the reality of governmental and non-governmental standards, one can conclude that there is already a set of well-defined rules in the WTO for governmental standards. The problem is how to establish transparent and non-discriminatory rules for non-governmental standards and to avoid that they be transformed in trade barriers. The Trading System is ready for the creation of an international body on market or private standards, which will bear responsibility for the negotiation of the basic rules for these standards and also to represent the interests of their stakeholders in other trade international fora, such as preferential agreements and the WTO - the meta-organization in charge of trade regulation.

\section{Conclusion}

The Trading System is facing a serious threat. A multiplication of barriers are being created by the creation of new regulations, standards and certifications affecting not only the trade of goods and services but also the production methods, labor standards and activities that impact 
the environment and climate, including emissions, animal welfare and geographic indication.

Regulatory measures are being used to differentiate products and can appear in technical regulations (mandatory) and standards (non-mandatory) for industrial products, sanitary and phitosanitary measures to food, voluntary standards related to labor, and voluntary or mandatory standards related to sustainability of production.

These regulations are being created by a multitude of bodies such as national governments or international governmental organizations as international standards; by international private associations as international private standards and incorporated by governments; or by the market through transnational enterprises imposing standards on their value chain and by non-governmental organizations or consumers associations as "voluntary" standards.

Governmental regulations and standards are already incorporated in the rules of WTO. However, developed countries are blocking the discussion of private and market standards in the WTO. They are not recognizing the effects that private standards are creating in the international trade. They are distorting trade, and under the responsibility of WTO members and its governments.

Private - market - non-governmental - transnational standards, whatever the chosen name, are important issues for developed countries, created mainly because of the concerns of their citizens. However countries are in different degrees of development and awareness in relation to sustainability demands. To transform private or market standards in significant barriers to trade could cause a bigger threat that is to undermine the whole meta-structure of the WTO, created by a huge effort of its members, along the last seventy years.

In the present Global World of production and consumption, in the era of global governance, new barriers should not be imposed to the developing countries but be discussed in the only forum that has a multilateral dimension. 


\section{FINAL CONCLUSIONS}

The rise of a polycentric world, the crises of multilateralism, the weakening of the main internal organizations are creating three serious threats to the Multilateral Trading System.

First, the political impasse between developed and emerging countries to conclude the last round in the WTO is a consequence of the strategy from some developed countries to remove the WTO from de center of the Trading System. The serious deadlock to conclude the last round of the multilateral negotiation at the WTO is a clear way to impose the new generation of the US and EU agreements as the new rule makers of the system. As a result, the fragmentation of trade rules by the multiplication of preferential agreements is creating a new sort of barriers for the excluded countries, among them, several relevant emerging countries and many least developing countries.

Second, the arrival of a new model of global production and trade leaded by global value chains is threatening the old trade order based in tariffs, defense remedies, rules of origin, called by experts as the WTO 1.0. The new model is creating a new set of regulations on investments, competition, customs and intellectual property. Either these issues are brought to the WTO or they will be negotiated in the new generation of agreements and then imposed to the system as a WTO 2.0.

Third, the main actors of the old Trading System were governments and industrial and services associations. The new actors of the System are now the consumers and workers mainly from the developed World. They are placing a lot of pressure on their governments to act in response of their new concerns: environment, climate change, labor standards, and animal welfare among others. Their pressure is changing the behavior of enterprises and their global value chains, and multiplying the rules for new standards and certifications.

Many of these new rules, standards and certifications are being adopted by the governments, others are imposed by enterprises along 
their value chains and a new wave of regulations, without control on their legitimacy or accountability, are being created by private bodies, non-governmental organizations or group of consumers, and are being spread and imposed along the international trade. The only big problem is that consumer needs from developed countries are not exactly the same as the ones for many developing countries.

These three important trends, the new generation of preferential agreements, the value chains and the market standards are not only impacting the Trading System, its structure, rules and instruments of action, but they are also damaging its whole framework constructed along the last 70 years. In addition, they are creating a new and severe divide between develop, some emerging and many least developed countries.

The dilemma is clear - either these three new threats are analyzed and a new set of rules are negotiated among all the players in a multilateral way - that is in the WTO - or the new Global Trading Order will be split by a new war, a regulatory war, that will divide the Global Trade Order in the Global North against the Global South. 